\title{
Parents' Behavior Related to Caries Status of Children with Down Syndrome in Surabaya
}

\author{
Tania Saskianti, DDS, PhD, Ardianti Maartrina Dewi, DDS, Nur Masyitah Iskandar Putri, DDS and Andi Octafianto, DDS
}

Department of Pediatric Dentistry, Faculty of Dental Medicine, University of Airlangga, Surabaya, Indonesia

\begin{abstract}
Background. Down syndrome (DS) is a chromosome disorder due to the presence of all or part of a third copy of chromosome 21 (trisomy 21) caused by a failure in chromosome segregation. Following Riset Kesehatan Dasar (RISKESDAS) in 2013, the number of people with DS in Indonesia increased compared to 2010, with an estimated 924 children with DS in Surabaya. Data regarding caries status in children with DS in Surabaya is limited.

Objective. To evaluate parents' behavior (predisposing, enabling, and reinforcing factors) related to the caries status of children with DS.

Methods. This observational analytic cross-sectional study included children aged $\leq 18$ years with DS and parents who were members of the Parents' Association of Children with Down Syndrome (POTADS). Caries status were measured using the DMF-T/def-t score, and parents were asked to fill out a questionnaire. Data were analyzed using Spearman's correlation test.
\end{abstract}

Result. We included 46 children with DS in this study. The DMF-t / def-t index of children with DS (7.2) was categorized as very high according to WHO. There was a significant relationship between lack of knowledge of parents and caries status in children with DS. Enabling factors and reinforcing factors were not significantly correlated with caries status.

Conclusion. Parents' behavior is correlated with the caries status of children with DS. All combination of three factors behavior, including predisposing, enabling and reinforcing, are needed to reduce the number of caries in children with DS.

Key Words: behavior, caries, Down syndrome, DMF-T/def-t

Paper presented in the Annual Scientific Meeting in Pediatric Dentistry, held by Indonesian Society of Pediatric Dentist, Pertemuan IImiah Nasional (PIN IKGA 13) on March 13-14, 2020, at Bali, Indonesia.

Corresponding author: Tania Saskianti, DDS, PhD

Department of Pediatric Dentistry

Faculty of Dental Medicine

University of Airlangga

Surabaya, Indonesia

Email: taniapedo@yahoo.com

\section{INTRODUCTION}

Down syndrome (DS) is a chromosome disorder due to the presence of all or part of the third copy of chromosome 21 (trisomy 21) caused by a failure in chromosome segregation. DS was discovered in 1866 by Dr. John Longdon Down. ${ }^{1}$ Following Riset Kesehatan Dasar (RISKESDAS) in 2013, the number of people with DS in Indonesia increased compared to 2010, with an estimated 924 children with DS in Surabaya. ${ }^{2,3}$

A community service on dental and oral prevention and care held by The Pediatric dentistry department Faculty of Dental Medicine Universitas Airlangga in 2017 found that out of 34 children with DS, about $60 \%$ of them had DMF-T/ def-t score that was categorized as high. ${ }^{4}$ Currently, there is contradictory data on the caries status of children with DS. Some studies showed that children with DS have lower caries compared to adults. Delayed tooth eruption, agenesis, microdontia, and spacing, are thought to be the reasons for 
Table 1. Relationship between predisposing factors and DMF-T/def-t score of children with Down syndrome

\begin{tabular}{|c|c|c|c|c|c|c|}
\hline \multirow{2}{*}{$\begin{array}{l}\text { Predisposing } \\
\text { Factors }\end{array}$} & \multicolumn{2}{|c|}{$\begin{array}{l}\text { DMF-T/def-t } \\
\text { (low) }\end{array}$} & \multicolumn{2}{|c|}{$\begin{array}{l}\text { DMF-T/def-t } \\
\text { (high) }\end{array}$} & \multirow[t]{2}{*}{ Total } & \multirow[t]{2}{*}{ Significance } \\
\hline & $\mathbf{N}$ & $\%$ & $\mathbf{N}$ & $\%$ & & \\
\hline Not good & 10 & 34.4 & 19 & 65.6 & 29 & \multirow{3}{*}{$\begin{array}{c}\text { Correlation coefficient }=0.67 \\
\qquad \text {-value }=0.00\end{array}$} \\
\hline \multirow[t]{2}{*}{ Good } & 3 & 17.6 & 14 & 82.4 & 17 & \\
\hline & 13 & & 33 & & 46 & \\
\hline
\end{tabular}

Table 2. Frequency distribution of knowledge of parents of children with Down syndrome

\begin{tabular}{lrrrc}
\multicolumn{1}{c}{ Knowledge } & True & $\%$ & False & $\%$ \\
\hline Frequency of brushing teeth & 26 & $56.5 \%$ & 20 & $43.5 \%$ \\
Time to brushing teeth & 5 & $10.9 \%$ & 41 & $89.1 \%$ \\
Cause of cavities & 7 & $15.2 \%$ & 39 & $84.8 \%$ \\
Fluoride toothpaste & 9 & $19.6 \%$ & 37 & $80.4 \%$ \\
Time to visit the dentist & 24 & $52.2 \%$ & 22 & $47.8 \%$ \\
Age to starting dental examination & 21 & $45.7 \%$ & 25 & $54.3 \%$ \\
\hline
\end{tabular}

low caries rate. However, the low oral $\mathrm{pH}$ value in children with DS due to food residue at interdental areas may lead to demineralization and higher caries prevalence. ${ }^{5}$

Children with DS who are younger than 8 years of age are unable to do daily toothbrushing due to their limited motor skills, intellectual disability, and limited sensory function. Thus, they need parents' or caregivers' assistance in brushing their teeth. ${ }^{5,6}$ Unfortunately, parents often prioritize medical treatment and tend to postpone dental visits. ${ }^{7}$

Information regarding parents' behavioral factors affecting the dental health of children with DS is scarce. There are different opinions and the cause is still unknown. Proper attempts and plans to overcome the challenging oral health problem cannot be made unless the cause is found. Parents' behavior is affected by three factors, namely predisposing, enabling, and reinforcing factors. ${ }^{8}$ The aim of this study was to correlate parents' behavior based on predisposing, enabling, and reinforcing factors to the caries status in children with DS in Surabaya.

\section{MATERIALS AND METHODS}

\section{Study Design and Population}

This cross-sectional and analytical observational study enrolled children with DS aged of $\leq 18$ years old and their parents as respondents through total enumeration sampling. The respondents also participated in community service for Parents' Association of Children with Down Syndrome (POTADS) in the Pediatric Dentistry Clinic of a hospital in Surabaya, Indonesia, the Rumah Sakit Gigi dan Mulut Universitas Airlangga (RSGM UNAIR). The study design was approved by Faculty of Dental Medicine, Universitas Airlangga Health Research Ethical Clearance Commission, certificate No: 703/HRECC.FODM/X/2019.

\section{Procedure}

The inclusion criteria of the study were: 1) Parents who signed informed consent; 2) Parents of children with DS aged $\leq 18$ years who were willing to fill up the questionnaire; 3) Literate parents; 4) Children with DS aged $\leq 18$ years. The present study deployed a questionnaire to measure parents' behavior. It consisted of 42 questions, including predisposing factors, enabling factors, and reinforcing factors. The questionnaire passed the validity test and pretested to 30 respondents. The trial results were not included as a sample. The caries status was measured using the DMF-T/def-t index, which was calculated as follows: a total of decay $(d)+$ missing $(\mathrm{m})+$ filling ( $\mathrm{f}$ ) and divided by the number of examined persons. The DMF-T/def-t categories include: 1) $<1.2=$ very low; 2) 1.2 to $2.6=$ low; 3) 2.7 to $4.4=$ moderate; 4) 4.5 to $6.5=$ high; 5) $>6.5=$ very high. The data obtained from the questionnaire of parent's behavior were processed using SPSS 25; the data were analyzed using Spearman technique.

\section{RESULTS}

The respondents involved 46 children with DS and their parents. The mean DMF-T/def-t score (7.2) was categorized as very high, according to WHO. There was a significant relationship between the predisposing factor and caries status of children with DS measured using DMF-T/ def-t index (Table 1).

The predisposing factor was viewed based on three aspects: namely, knowledge, attitude, and behavior. The questionnaire revealed that $87 \%$ of the parents did not have adequate knowledge of dental and oral health in children with DS about $43.50 \%$ of parents of children with DS did not make a correct answer regarding tooth brushing frequency, $89.1 \%$ of parents did not know the right time to brush the teeth, $84.8 \%$ did not know the causes of tooth decay, and $47.8 \%$ of them did not know the right time for a periodic dental visit (Table 2).

There was no significant relationship between enabling factors and caries status of children with DS (Table 3).

Based on the result of the study, it was found that the parents of children with DS supported their children's dental health, they supported and facilitated their children for dental visit. The parents provided health insurance and were willing to conduct periodic consultation with a pediatric dentist (Table 4). 
Table 3. Relationship between enabling factors and DMF-/def-t score of children with Down syndrome

\begin{tabular}{|c|c|c|c|c|c|c|}
\hline \multirow{2}{*}{$\begin{array}{l}\text { Enabling } \\
\text { Factors }\end{array}$} & \multicolumn{2}{|c|}{$\begin{array}{l}\text { DMF-T/def-t } \\
\text { (low) }\end{array}$} & \multicolumn{2}{|c|}{$\begin{array}{l}\text { DMF-T/def-t } \\
\text { (high) }\end{array}$} & \multirow[t]{2}{*}{ Total } & \multirow[t]{2}{*}{ Significance } \\
\hline & $\mathbf{N}$ & $\%$ & $\mathbf{N}$ & $\%$ & & \\
\hline Not good & 4 & 25 & 12 & 75 & 16 & \multirow{3}{*}{$\begin{array}{c}\text { Correlation coefficient }=0.03 \\
\qquad \text {-value }=0.83\end{array}$} \\
\hline \multirow[t]{2}{*}{ Good } & 9 & 30 & 21 & 70 & 30 & \\
\hline & 13 & & 33 & & 46 & \\
\hline
\end{tabular}

Table 4. Frequency distribution of enabling factors of parents of children with Down syndrome

\begin{tabular}{llrrr}
\multicolumn{1}{c}{ Enabling factor } & Yes & $\%$ & No & \multicolumn{1}{c}{$\%$} \\
\hline Consultation to pediatric dentistry & 24 & $52.2 \%$ & 22 & $47.8 \%$ \\
Parents still go to the dentist despite obstacles & 45 & $97.8 \%$ & 1 & $2.2 \%$ \\
Health insurance & 28 & $60.9 \%$ & 18 & $39.1 \%$ \\
\hline
\end{tabular}

Table 7. Relationship between reinforcement factors and DMF-T/def-t score of children with Down syndrome

\begin{tabular}{|c|c|c|c|c|c|c|}
\hline \multirow{2}{*}{$\begin{array}{l}\text { Reinforcement } \\
\text { Factors }\end{array}$} & \multicolumn{2}{|c|}{$\begin{array}{l}\text { DMF-T/def-t } \\
\text { (low) }\end{array}$} & \multicolumn{2}{|c|}{$\begin{array}{c}\text { DMF-T/def-t } \\
\text { (high) }\end{array}$} & \multirow[t]{2}{*}{ Total } & \multirow[t]{2}{*}{ Significance } \\
\hline & $\mathbf{N}$ & $\%$ & $\mathbf{N}$ & $\%$ & & \\
\hline Not good & 1 & 13.6 & 6 & 86.4 & 7 & \multirow{3}{*}{$\begin{array}{c}\text { Correlation coefficient } \\
\qquad \begin{array}{c}=079 \\
p \text {-value }=0.601\end{array}\end{array}$} \\
\hline \multirow[t]{2}{*}{ Good } & 12 & 14.3 & 27 & 85.7 & 39 & \\
\hline & 13 & & 33 & & 46 & \\
\hline
\end{tabular}

Table 5. Frequency distribution of parents' inhibiting factors

\begin{tabular}{ccc}
\hline Parents' Inhibiting Factors & No. & $\%$ \\
\hline Cost & 19 & 41.3 \\
Working time & 27 & 58.7 \\
\hline
\end{tabular}

Table 6. Frequency distribution of parents' income (in Indonesian Rupiah)

\begin{tabular}{crc} 
Income & No. & $\%$ \\
$\leq 5$ million & 38 & 82.6 \\
$>5$ million & 8 & 17.4 \\
\hline
\end{tabular}

About $58.7 \%$ of the respondent state that the parent's working time makes them difficult to take their child to visit the dentist (Table 5).

The questionnaire showed that the cost dental visit is one of inhibit factor for them going to the dentist. Supported by data mentioning that $82.6 \%$ of the parent's earn less than 5 million rupiahs/ month as income (Table 6).

There was no significant relationship between reinforcing factors and caries status of children with DS (Tables 7 and 8).

\section{DISCUSSION}

Dental caries is a microbiological dental infection that leads to damaged dental calcification. ${ }^{9}$ Dental caries development is a dynamic and continuous process, including demineralization by the organic acid from microbes and remineralization of saliva component, where mineral loss

Table 8. Frequency distribution of reinforcing factors of parents of children with Down syndrome

\begin{tabular}{lcrrr}
\multicolumn{1}{c}{ Reinforcing factor } & Yes & \multicolumn{1}{c}{$\%$} & No & \multicolumn{1}{c}{$\%$} \\
\hline POTADS activities & 40 & 86.9 & 6 & 13.0 \\
Information from POTADS & 46 & 100.0 & 0 & 0 \\
Information from dentist & 29 & 63.0 & 17 & 37.0 \\
Quality service & 39 & 84.8 & 7 & 15.2 \\
\hline
\end{tabular}

POTADS, Parents' Association of Children with Down Syndrome is greater than the mineral gain. ${ }^{10}$ According to some researchers, the caries rate in children with DS is relatively low due to the number of teeth, delayed tooth eruption, hypodontia, a diastema, small mesiodistal, and high sIgA level. ${ }^{11}$ Other researchers state that caries may occur in children with DS when there is food residue, which leads to demineralization. ${ }^{5}$

Parents of children with DS have greater responsibility and must pay attention to the child's daily activities and development such as wearing clothes, self-cleaning, such as tooth brushing, due to limited motor function. They must also pay attention to the systemic conditions that occur in their children. ${ }^{12}$ The health behavior of parents are affected by predisposing, enabling, and reinforcing factors. Predisposing factors refers to factors facilitating the emergence of one's behavior comprising knowledge, attitude, and behavior. ${ }^{8}$

In this study the mean DMF-T/def-t score (7.2) was categorized as very high. There was a significant relationship between the predisposing factors and caries status of children with DS in Surabaya. Most parents did not have adequate knowledge of dental and oral health in children with DS, including the right time to brush teeth and causes of tooth decay. On other hand, less than 50\% of parents of children with DS did not correctly answer the question regarding tooth brushing frequency and the right time for a periodic dental visit. Most parents did not know basic knowledge about maintaining daily oral hygiene such as 
proper frequency and time to brush their teeth. Such a lack of knowledge may adversely affect the child's dental and oral health, considering that children with DS need the parents' assistance and monitoring regarding hygiene and tooth brushing. Mothers' lack in knowledge in dental health will mislead their children who imitate their mothers' behavior, given that they are the closest personw and role models for their children. ${ }^{13}$ There was a significant relationship between mother's knowledge and child's dental caries, indicating that the higher the mother's knowledge of dental health, the lower the caries risk. ${ }^{14}$

Parents' knowledge affects the caries status of children in terms of the mother's age, education, and occupation. Age is one of the factors determining one's maturity in thinking, acting, or learning. ${ }^{15}$ In the present study, more than $50 \%$ of mothers graduated from university. Their average age was 30 years an age at which the mother has maturity of thinking, acting, and learning. However, it was found that the DMF-T/def-t index was very high; this may be caused by the parents' lack of understanding on the importance of knowledge. Knowledge is a cognitive field with different levels, such as knowing, understanding, applying, analyzing, synthesizing, and evaluating. ${ }^{16}$ Knowledge is a result of 'knowing' and this emerges after sensing a certain object. The lower an individual's knowledge and awareness of maintaining and caring for their dental health, the higher risk of dental caries. ${ }^{8}$

Another factor, according to Lawrence Green, is the enabling factor. It is one of the factors which inhibit the parents' good health behavior. There was no significant relationship between the enabling factor and caries status of children with DS in this study. The parents of children with DS supported their children's dental health, and facilitated their children's dental visit. The parents provided health insurance and were willing to conduct periodic consultation with a pediatric dentist.

Concerning dental health access and facilities, the parents stated that they did not find difficulties to go to the dentist. Although they also perceived that the dentists were very informative and provided quality services, not all of them visit and consult with the dentist. This may be because not all regions have sophisticated medical staff such as a pediatric dentist to treat children with special needs. Parents took their child to a general dentist in Community Health Service Center near their home where there were no pediatric dentist specialist services available. Unfortunately this clinic did not provide adequate facilities to treat children with Down syndrome. Saeed and Mohamed reported that the use of dental care service and parents' satisfaction increased when the distance was relatively short and thrre were good facilities. ${ }^{17}$

Parents of children with DS support the child and provide better dental health using health insurance to facilitate dental visits. However, this is contradictory to the very high caries status of the children in this study. This is in contrast with previous studies that found a positive relationship between one's health behavior and health insurance use, where individuals with health insurance use his or her insurance for dental and oral care. ${ }^{18}$ The different result in this study may be accounted for by the fact that although the parents had facilitated their child's dental care with health insurance, they did not have enough time to take their child for a dental visit. Parents stated that working time and cost (insufficient income) were factors that hampered them from taking their child to the dentist. Most parents had a monthly income of less than 5 million, and not all parents had health insurance, forcing them to spent more money for the treatment. Some studies showed that parents, in general, tend to prioritize medical issues and delay dental visits for their children probably due to long working time and limited parent's income. ${ }^{5}$ Dental care utilization can be improved if the hospital provides high-quality dental care at a reasonable price. In Indonesia, as stated in a study, there is a relationship between the use of service and the information, service quality, and the health facility. ${ }^{17}$

One's socio-economic status affects his or her health; a family with low economic status tends to have children with high caries status because they will go to the dentist only when they get a toothache. This phenomenon indicates a problem relating to cost. ${ }^{19}$ Children of parents with adequate income have the opportunity to enjoy health services. Children of parents with sufficient income may enjoy better health services. ${ }^{20}$

The third factor proposed by Lawrance Green is the reinforcing factor; this factor refers to the factor supporting the emergence of behaviour. There was no significant relationship between the reinforcing factor and caries status of children with DS in this study. The parents' reinforcing factor was categorized as good; as seen in the parents' cooperation in activities held by POTADS. The caries status of children with DS was very high, may be because parents of children with DS had just joined POTADS for 1-3 years, and had not participated in oral and dental health community service held by this organization. They stated that these activities provided information and knowledge regarding their child's dental health, among other information. The significant role of POTADS and health workers was shown in the events they held. In addition, the support of public figures such as a teacher or dentist as a role model is considered important to form dental health behavior which can guide and develop community awareness. Guidance may start from family, school, and the environment around the house. ${ }^{21}$

Green's theory state that one's behavior is determined by three main factors, namely: predisposing factor, enabling factor, and reinforcing factor. Accordingly, one factor alone will not be able to form an individual's good behavior. With regard to Lawrence Green's Precede-Proceed Model, as cited by Notoatmojo ${ }^{8}$ states that a behavior exhibited by an individual is a result of a process of functional factors in the following formula: $\mathrm{B}=\mathrm{f}(\mathrm{Pf}, \mathrm{Ef}, \mathrm{Rf})$ where: $\mathrm{B}=$ Behavior as 
the dependent variable $\mathrm{f}=\mathrm{Pf}$ function $=$ Predisposing factors $\mathrm{Ef}=$ Enabling factors $\mathrm{Rf}=$ Reinforcing factors.$^{21}$

This study showed that parents' behavior was categorized as 'not good' and that children with DS had 70\% of normal DMF-T. On the other hand, another study that found $83 \%$ of children with DS to be caries-free compared to control (42.5\%). Caries-free condition is associated with the diet behavior of a child with DS, clean environment, controlled diet, hypodontia, microdontia, a diastema, saliva's high $(\mathrm{pH})$ concentration, and delayed eruption pattern. ${ }^{22,23}$ This study concurs with other studies that found similar DMF-T/ def-t scores in individuals with DS and healthy children. This was caused by low awareness of oral health among the population, lack of preventive programs, and bad oral health promotion. In addition, lack of knowledge regarding good oral health practice between the parents and the caregiver, lack of motivation, low priority on dental care, and lack of facilities for early, periodic dental care were also contributory factors. ${ }^{7}$

\section{CONCLUSION}

Parents' behavior is correlated to caries status in children with DS. To reduce the caries rate, three factors (i.e., predisposing, enabling, and reinforcing factor) on parents' behavior should be improved.

\section{Acknowledgment}

The authors would like to thank the patients for giving informed consent for this study and the Community Service Grant from Faculty of Dental Medicine Universitas Airlangga 2019, who fully funded the research.

\section{Statement of Authorship}

All authors participated in the data collection and analysis and approved the final version submitted.

\section{Author Disclosure}

All authors declared no conflicts of interest.

\section{Funding Source}

This research was fully funded by Community Service Grant from Faculty of Dental Medicine Universitas Airlangga 2019.

\section{REFERENCES}

1. Pasca RA. Improving life skill in children with Down Syndrome by using modeling technique. Pers J Psikol Indones. 2016;5(03):215-25.

2. Mujaddid. The health of children with disabilities. Bul Jendela Data Inf Kesehat. 2014;Semester 2(1):1-5.
3. Mulia Amanda. Down syndrome child therapy facility in Surabaya. J Edimensi Arsit. 2012;1(1):1-6.

4. Dewi AM, Tania S, Moeharyono PM. Dental Health Condition and Treatment Need in Children with Down Syndrome. Dent Heal Cond Treatment Need Child with Down Syndr. 2017;

5. Descamps I, Marks LA. Oral health in children with down syndrome: Parents' views on dental care in Flanders (Belgium). Eur J Paediatr Dent. 2015;16(2):143-8.

6. Rahma MS, Indrawati ES. Parenting experience of a Down syndrome child (Phenomenological qualitative in the working mother). J Empati. 2017;7(No. 3):223-32.

7. Porovic S, Zukanovic A, Juric H, Dinarevic and. Oral Health of Down Syndrome Children in Bosnia and Herzegovina. Mater Socio Medica. 2016;28(5):370.

8. Notoatmodjo S. Health promotion and health behavior. Jakarta: Rineka Cipta; 2014. p. 18-19.

9. Rao A. Principles and Practice of Pedodontics. 2nded ed. New Delhi: Jaypee Brothers Medical Publisher; 2008. 175 p.

10. McDonald RE, Avery DR. Dentistry for The Child and Adolescent. Tenth edit. Missouri: Elsevier; 2016. 185-205 p.

11. Article R, Kazemi M, Salehi M, Kheirollahi M. Down Syndrome: Current Status, Challenges and Future Perspectives. Int J Mol cell Med. 2016;5(3):125-33.

12. Lestari FA. The resilience of mothers who have Down syndrome children in Sidoarjo. Psikologia. 2015;1(1):141-55.

13. Hermawan RS, Warastuti W, Kasianah. The factors that influence teeth and oral health of preschool-age children in early childhood education of Perlita Vinolia SUb Distric Mojolangu.J keperawatan. 2015;132-41.

14. Noviani N. The Factors Associated with Dental Caries Status (DMF-T) of Al-Ashariyyah Islamic Boarding School' Santri, Nurul Iman Parung Bogor. University of Indonesia; 2010.

15. Yulianti PR, Abi M. The relationship between parental knowledge about oral health and dental incidence in children at SDN V Jaten Karanganyar. J Univ Muhammadiyah Surakarta. 2009;4(1):25-34

16. Budiarto. Introduction to Health Behavioral Science and Health Education. 1 st. Juwono L, editor. Jakarta: EGC; 2008. 18-19 p.

17. Tasya N, Andriany P. RSGM Syiah Kuala University Banda Aceh: A hospital under the auspices of the Faculty of Dentistry. J Caninus Dent. 2016; 1 (1): 54-62.

18. Feblina A. actors who influence the utilization of health services and the impact on quality of life related to oral health at the Tolo Public Health Center, Jeneponto Regency in 2017. Hasanuddin University; 2017.

19. Devishree RA, Arumugham M, Jain AR. The role of social economic status on dental caries and its prevention among outpatients visiting private dental college hospital. J Pharm Sci Res. 2018;10(2):369-71.

20. Nantung RA, Pangemanan DHC, Gunawan PN. The Effect of Parents' Socioeconomic Level on Caries in children at Kindergarten Hang Tuah Bitung. e-TEETH. 2015; 3 (2): 1-7.

21. Harahap RA. The Influence of Predisposing, Enabling and Reinforcing Factors on Giving Hepatitis B Immunization to Infants at Public Health Center Bagan Batu, Bagan Sinembah District, Rokan Hilir Regency. J Ilm Health Researcher, Public Health Faculty of Islamic University of North Sumatra. 2016; 1 (1): 79-103.

22. Gupta PV. Pediatric Dentistry for Special Child. New Delhi, India: Jaypee brothers; $2016.269 \mathrm{p}$.

23. Rosdiana R, Rizal MF. The relation between salivary sIgA level and caries incidence in Down syndrome children. Dent J (Majalah Kedokt Gigi). 2012;45(2):79. 